
Not for reproduction, distribution or commercial use.

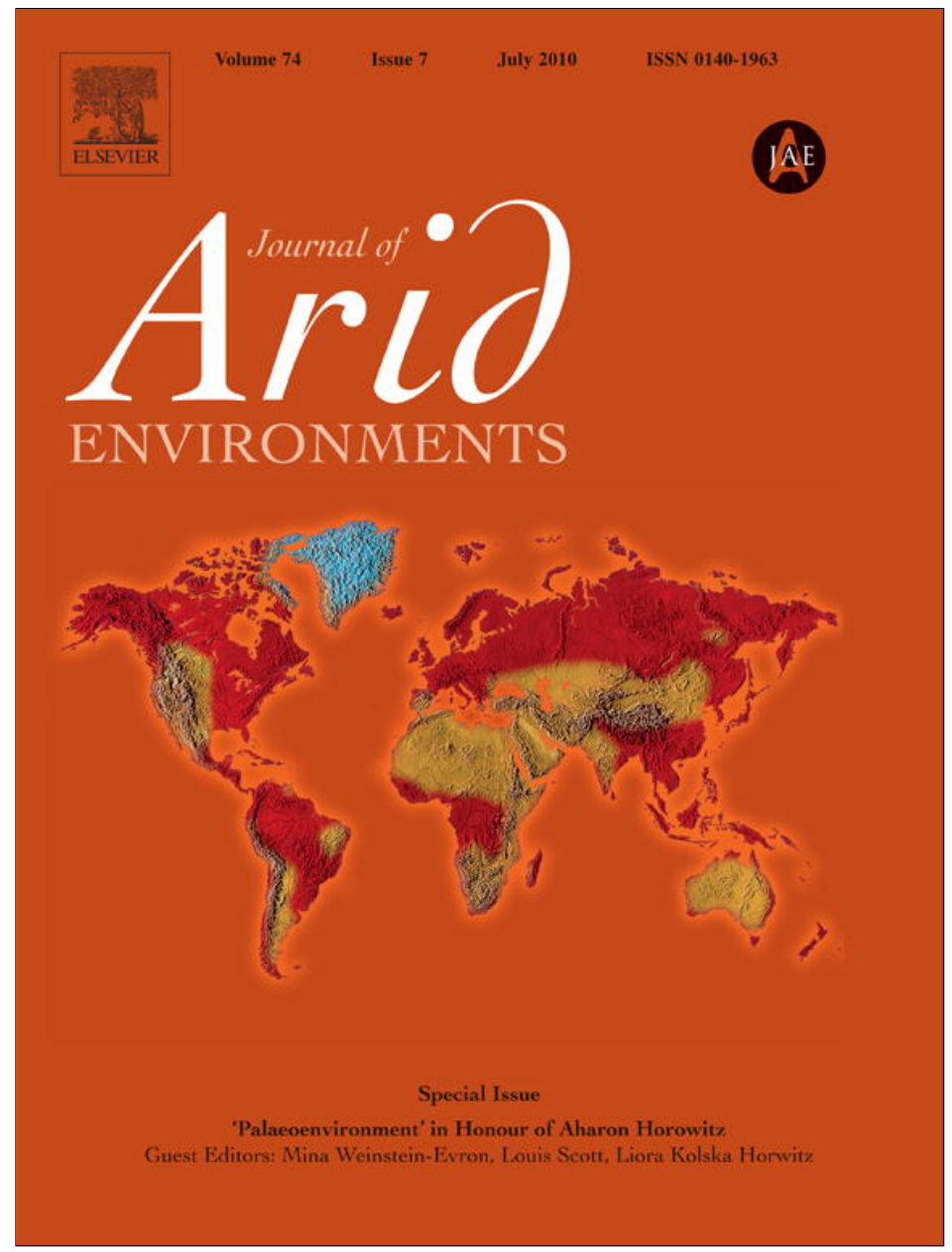

This article appeared in a journal published by Elsevier. The attached copy is furnished to the author for internal non-commercial research and education use, including for instruction at the authors institution and sharing with colleagues.

Other uses, including reproduction and distribution, or selling or licensing copies, or posting to personal, institutional or third party websites are prohibited.

In most cases authors are permitted to post their version of the article (e.g. in Word or Tex form) to their personal website or institutional repository. Authors requiring further information regarding Elsevier's archiving and manuscript policies are encouraged to visit:

http://www.elsevier.com/copyright 


\title{
Vegetation history and climate fluctuations on a transect along the Dead Sea west shore and their impact on past societies over the last 3500 years
}

\author{
F.H. Neumann ${ }^{\text {a,b,c,* }}$, E.J. Kagan ${ }^{\text {d,e }}$, S.A.G. Leroy ${ }^{\text {f }}$, U. Baruch ${ }^{\mathrm{g}}$ \\ ${ }^{a}$ Department of Plant Sciences, Faculty of Natural and Agricultural Sciences, University of the Free State, PO Box 339, Bloemfontein 9300, South Africa \\ ${ }^{\mathrm{b}}$ Steinmann-Institute for Geology, Mineralogy and Palaeontology, University of Bonn, Nussallee 8, 53115 Bonn, Germany \\ ${ }^{c}$ Bernard Price Institute for Palaeontological Research, University of the Witwatersrand, Private Bag 3, Wits 2050, South Africa \\ ${ }^{\mathrm{d}}$ Geological Survey of Israel, 30 Malkhei Israel Street, Jerusalem 95501, Israel \\ e Institute of Earth Sciences, Givat Ram, The Hebrew University, Jerusalem 91904, Israel \\ ${ }^{\mathrm{f}}$ Institute for the Environment, Brunel University, Uxbridge UB8 3PH, West London, UK \\ g 99 Hashalom street, Mevasseret Ziyyon 90805, Israel
}

\section{A R T I C L E I N F O}

\section{Article history:}

Received 25 April 2008

Received in revised form 16 April 2009

Accepted 17 April 2009

Available online 28 May 2009

\section{Keywords:}

Holocene

Israel

Palynology

Vegetation transect

\begin{abstract}
A B S T R A C T
This study represents the vegetation history of the last 3500 years and conducts an analysis of the climatic fluctuations on a $75 \mathrm{~km}$ long transect on the western Dead Sea shore. Palynological and sedimentological data are available from six cores near Mount Sedom, Ein Boqueq, and Ein Gedi and from outcrops near Ze'elim and Ein Feshkha. The comparison of the pollen data with the lake levels shows synchronous trends. During the Middle Bronze Age, Iron Age and Hellenistic to Byzantine Period the high lake level of the Dead Sea signals an increase in precipitation. Contemporaneously, values of cultivated plants indicate an increase in agriculture. Lake level is low during the Late Bronze Age, within the Iron Age and at the end of the Byzantine period, indicating dry periods when all pds show a decrease of cultivated plants. Forest regeneration led by drought-resistant pines is observed in all pollen diagrams (pds) following the agricultural decline in the Byzantine period and, in the pds near Ein Boqeq, Ze'elim and Ein Feshkha, during the late Iron Age. The modern vegetation gradient is reflected in the palaeorecords: a stronger expansion of Mediterranean vegetation and cultivated plants in the northern sites is recognisable.
\end{abstract}

(c) 2009 Elsevier Ltd. All rights reserved.

\section{Introduction}

The rise and fall of Near-Eastern civilisations are often discussed within the archaeological community in terms of socio-economic determinism. High-resolution palaeoclimatic data, however, give evidence of climatic fluctuations correlating with historical or archaeological data (Weiss and Bradley, 2001). The Dead Sea region is suitable for the exploration of links between climate, vegetation and settlement history because it is characterised by climatic contrasts, is close to centres of settlement and agriculture (e.g. Judean Hills) and has itself been an economic resource for $\sim 10000$ years (Nissenbaum, 1993). Crucial for the discussion of climate change are reconstructions of the Holocene Dead Sea lake levels (Bookman et al., 2006; Bookman (Ken-Tor) et al., 2004; Enzel et al., 2003; Frumkin, 1997; Frumkin and Elitzur, 2002; Frumkin et al., 1991; Klein and Flohn, 1987; Klinger et al., 2003; Migowski

\footnotetext{
* Corresponding author at: Bernard Price Institute for Palaeontological Research, University of the Witwatersrand, Private Bag 3, Wits 2050, South Africa.

E-mail address: fneumann@uni-bonn.de (F.H. Neumann).
}

et al., 2006; Neev and Emery, 1967). Several cores from the western shore of the Dead Sea were used for palynological investigations during the 1990s, but pollen records span maximally 3000 years and few radiocarbon ages were available (Baruch, 1990, 1993; Heim et al., 1997). High-resolution palynological and sedimentological investigations from two erosional gullies at the western shore of the Dead Sea (Ze'elim and Ein Feshkha) revealed a relationship between vegetation dynamics, climate and human impact based on comparison with fluctuations of the Dead Sea (Neumann et al., 2007). Therefore pollen data from six sites spanning a north-south transect of $75 \mathrm{~km}$ along the shore of the Dead Sea with a temperature and rainfall gradient provide the possibility of highlighting synchronous changes in vegetation in different eco-regions.

\section{Morphology and geology of the Dead Sea area}

The Dead Sea water level, $418 \mathrm{~m}$ bsl (meters below sea level) in 2006, has dropped by $1 \mathrm{~m} /$ year since the 1980s (Gavrieli et al., 2006). Approximately $90 \%$ of the flow that would reach the lake from the Jordan River is diverted by surrounding countries (Dayan 
and Morin, 2006). The lake is located in a pull-apart basin along the Dead Sea Transform fault (DST, Freund et al., 1970; Garfunkel and Ben-Avraham, 1996). Since the Neogene the depressions along the DST were filled by lakes (Stein, 2001) and in the Holocene the Dead Sea itself developed. The sediments (fluvial, fan deltas, shores, and lacustrine) comprise the Ze'elim Formation, which is exposed in erosion gullies at the shores and accessible in drillholes (Bookman (Ken-Tor) et al., 2004; Yechieli et al., 1993). The channel incision is a response to base level lowering due to lake level drops (Ben Moshe et al., 2008).

\section{Climate, water and vegetation around the Dead Sea}

Israel and western Jordan are in the winter rain climate zone. In winter, cyclones bring rain while the summer is dry and hot (Walter and Breckle, 1999). Rainfall and temperature are influenced by topography. The rift valley is a rain shadow desert. The rainfall declines from 600 to $700 \mathrm{~mm} /$ year near Jerusalem to $<400 \mathrm{~mm} /$ year in the Negev and around $100 \mathrm{~mm} /$ year at the shore of the Dead Sea and in the Arava valley to the S (Fig. 1B). Fluctuations of the Dead Sea lake level are induced by rainfall changes (Dayan and Morin, 2006). In winter rain climates, evaporation varies little annually, but rainfall fluctuations are high, so that the variability of evaporation plays only a minor role (Klein and Flohn, 1987). The main watercourse is the Jordan River. Most of the wadis draining the Judean Hills and the highlands of Moab and Edom are dry with the exception of winter floods from October through May. Few perennial streams such as Wadi el Mujib in Jordan discharge into the lake (El-Naqa, 1993). Springs like Ein Feshkha, fed by aquifers from the Judean Hills, emerge along the flanks of the Dead Sea (Ben-Itzhak and Gvirtzman, 2005). Winds, a consequence of depressions during winter and spring, are mostly westerlies (Hecht et al., 1997). Topography can change the general wind direction to the north or northwest (Bitan, 1974). Dust deposition rates peak during spring blossoming period and autumn. A grain size distribution curve for atmospheric dust deposition shows that the dust

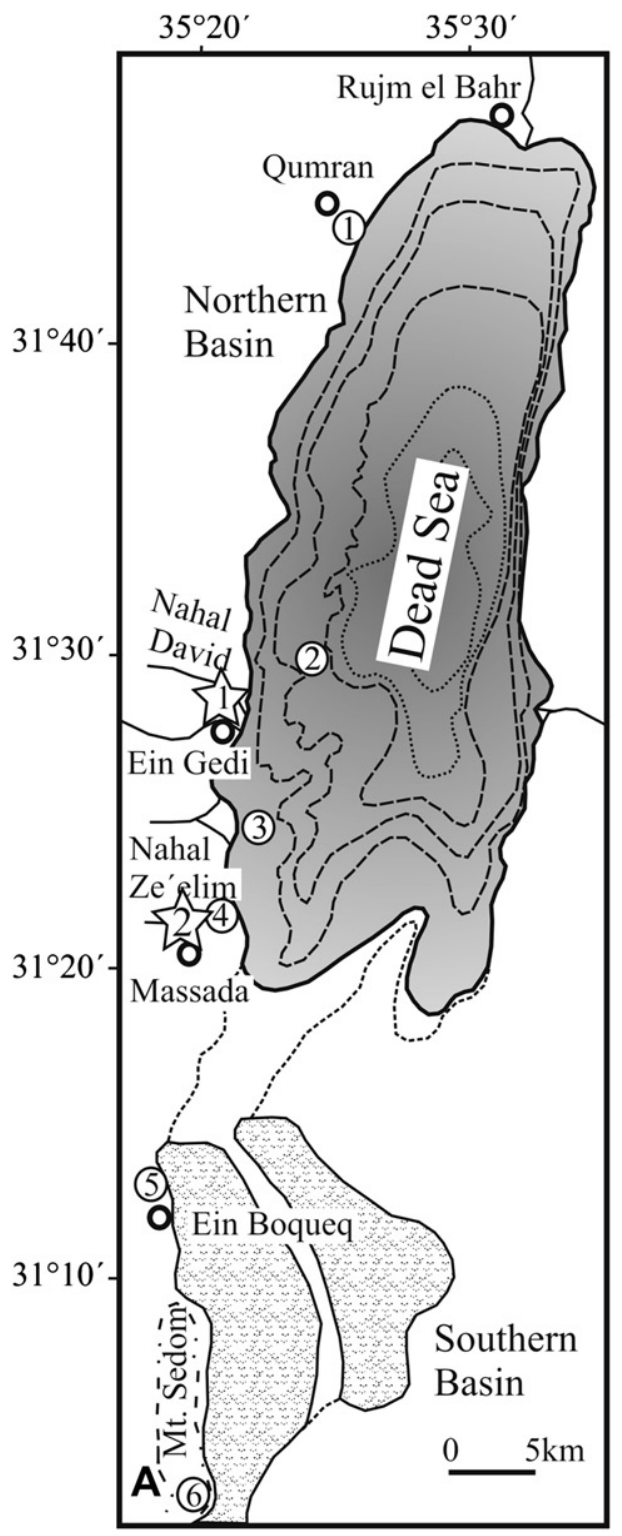

Pollen analysis

(1) outcrop EFE, Ein Feshkha (2) core DS7-1SC, NE of Ein Gedi 论 outcrop Nahal Ze'elim

(3) core DS1, SE of Ein Gedi

(4) outcrop Za2, Ze'elim

(5) core DS2, Ein Boqueq

(6) core DS3, Mt. Sedom

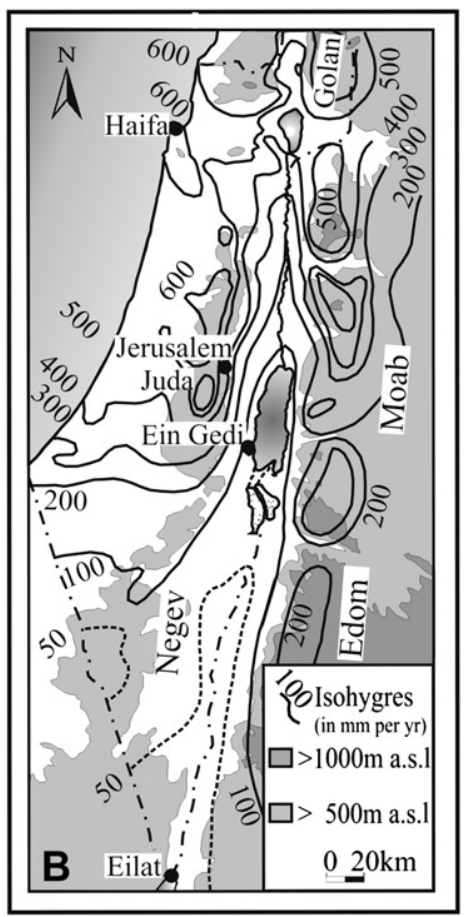

Lake level reconstruction 谓 outcrop Nahal David

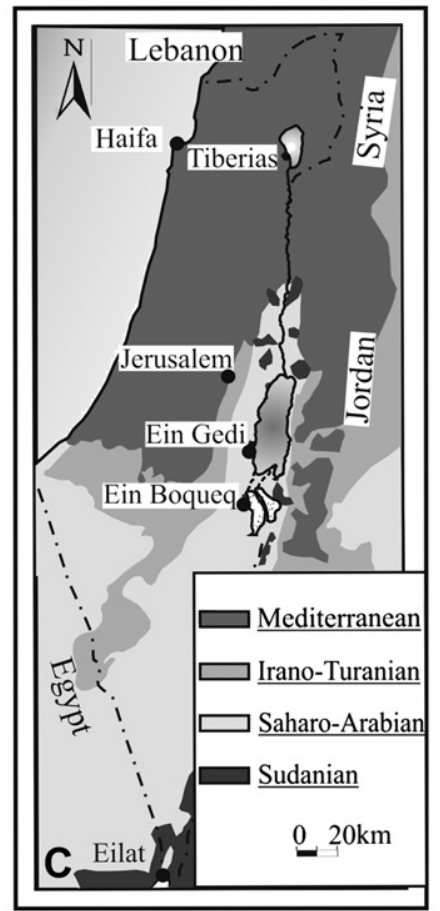

Fig. 1. A: Map of the Dead Sea showing the location of the cores and outcrops used for palynological and sedimentological research and discussed in this paper (after Baruch, 1990 , 1993; Bookman (Ken-Tor) et al., 2004; Heim et al., 1997; Neumann et al., 2007), B: Topographical map of Israel and adjacent areas, black lines: annual rainfall contour lines in mm/year (after Jaffe, 1988),C: Plant geographical territories of Israel and adjacent areas (after Danin, 1988). 
(including pollen) is primarily of long and mid-range transported origin (Singer et al., 2003). The vegetation geography of Israel and western Jordan depends on precipitation gradient. Four plant geographical territories are defined by statistical methods for the Israeli territory: the Mediterranean, the Irano-Turanian, the SaharoArabian, and the Sudano-Deccanian territories which meet at the Dead Sea (Fig. 1B) (Danin and Orshan, 1999; Danin and Plittmann, 1987). Mediterranean trees are Olea europea, Quercus calliprinos, summergreen oaks (e.g. Quercus boisseri at $>400 \mathrm{~m}$ asl; FeinbrunDothan and Danin, 1991), Ceratonia siliqua and Pinus halepensis. In the mountains of southern Jordan Juniperus phoenicia grows (Al-Eisawi, 1996). At the transition towards the steppe Sarcopoterium spinosum is abundant (Baruch, 1993; Danin, 1988). Irano-Turanian steppe elements (precipitation $<300 \mathrm{~mm} /$ year) are Artemisia sp. and Retama raetam (Danin, 1995). The Saharo-Arabian territory is characterised by a desert climate $(<100 \mathrm{~mm} /$ year$)$ with salt-tolerant Chenopodiaceae and Tamarix (Al-Eisawi, 1996; Zohary, 1983). This vegetation is abundant at the Dead Sea level. The Sudano-Deccanian territory includes the oases at the coasts of the Dead Sea where Acacia sp., Moringa peregrina, Ziziphus spina-christi, Salvadora persica and Phoenix dactylifera grow (Al-Eisawi, 1996; Zohary, 1995). Human pressure has resulted in the degradation of vegetation and alien species were introduced as crops or as weeds (Danin, 1995).

\section{Palynological records at the Dead Sea}

We present vegetation developments from six pollen diagrams (pds) near Ein Gedi (2pds), Ein Feshkha, Ze'elim, Ein Boqueq, and Mount Sedom (Baruch, 1993; Heim et al., 1997; Neumann et al., 2007). Pollen records span the period between the Late Bronze Age and the 20th century. Since limited information about the Middle Bronze Age and the transition between the Neolithic and Chalcolithic are only available from Ze'elim (Neumann et al., 2007) we will concentrate on the vegetation development since the Late Bronze Age. The sites will be discussed from south to north. Appendices $1-6$, containing selected pollen curves of the individual pollen diagrams with lithology and chronology, are only published in the electronic version of this paper. Uncalibrated radiocarbon dates from cores DS2 and DS7-1SC were calibrated in this study using CALIB 5.0.2 in conjunction with Stuiver and Reimer (1993). Discussions of the chronologies of each diagram have been previously published. Here we correlate the pollen zones directly to archaeological and historical periods.

\subsection{Core DS3 (Mount Sedom)}

An $11 \mathrm{~m}$-long core from the Sedom saltpan was prepared and analysed by B. Lanjouw in 1978 (at the Biological-Archaeological Institute of Groningen University), but never published in a journal. A concise version of the diagram is presented and discussed in Baruch $(1990,1993)$ (Appendix 1). The DS3 pd, like the pds of cores DS1 near Ein Gedi and DS2 near Ein Boqeq (Fig. 1), is tentatively dated by correlation with the radiocarbon dated pd of Lake Kinneret on the basis of fluctuations of major pollen curves, e.g. Olea and Pinus (Baruch, 1993). Due to low Q. calliprinos values characterising the pds of DS3 and Lake Kinneret, the profile probably starts at $\sim 1000 \mathrm{yr} B C$.

Zone X - ca. 1000-350 yr BC (Middle to Late Iron Age): The low values of $Q$. calliprinos might be a result of anthropogenic activities in the lower forest belt (Baruch, 1990). Since $Q$. boisseri might have been restricted to the northern part of the Judean hills percentages are low. Anthropogenic indicators, e.g. Plantago lanceolata and Sarcopoterium, are rare. Tree pollen values vary $\sim 10 \%$. Olea reaches $\sim 8 \%$ at the end of the zone indicating limited cultivation.
Zone $Y$ - $350 y r$ BC-AD 550 (Hellenistic-Roman-Byzantine period): An increase of Olea (15\%) indicates major human activity. The Olea expansion culminates during the first quarter of the past millennium, i.e. the Roman-Byzantine period, reflecting wide expansion of olive cultivation during this period. $\mathrm{C}^{13}$ values from wood in the Roman Masada ramp point to humid conditions (Yakir et al., 1994). The Olea curve declines at the transition to the Early Arab period, probably as a result of contraction of olive cultivation, attributed to geo-political changes. At the end of this period, pollen grains of S. spinosum, a distinctive anthropogenic indicator, become prominent.

Zones Z1, Z2, Z3 AD 550-present (Arab-Modern period): Pinus values are increasing to $\sim 14 \%$ in sub-zone $Z 1$. This episode of pine expansion can be explained by its peculiar ecology (Baruch, 1990; see chapter 6 for details). In Z2 the curve of $Q$. calliprinos reaches its climax and a southward migration of the maquis is assumed. The culmination of the evergreen oaks in the 16-17th century AD may be explained as a result of the decrease of anthropogenic pressure on the Mediterranean maquis due to population decrease. However, as this period also correlates with the Little Ice Age a climatic factor cannot be ruled out (Lamb, 1982). The subsequent drop of evergreen oaks may be explained by a combination of a decrease in precipitation at the end of the Little Ice Age and renewed anthropogenic pressure on the vegetation, resulting from the onset of the Industrial Revolution.

\subsection{Core DS2 (Ein Boqueq)}

A $5.20 \mathrm{~m}$-long core from the southern basin of the Dead Sea near Ein Boqueq was retrieved by U. Baruch in 1987 with the help of the late Professor S. Bottema of the Biological-Archaeological Institute of Groningen University. The palynological analysis of this core is from Baruch's Ph.D. dissertation (Baruch, 1993), but the pollen diagram has never been fully published (Appendix 2 ).

Zone X - ca. 1000-350 yr BC (Middle to Late Iron Age): The low Quercus values in this zone may reflect forest decimation as a result of anthropogenic activities. The rather high Olea values $(\sim 8 \%)$ in the middle of sub-zone $\mathrm{X} 1$, accompanied by marked Vitis values, which remain high throughout this and the following zone $(\mathrm{Y})$, points to cultivation. The local vegetation was dominated by chenopods, which fluctuate markedly. This may point to shifts of the local coastline, resulting from slight modifications in lake level since the lake in this area is very shallow. Forest regeneration, which may have resulted from temporary ease of anthropogenic pressure on the vegetation, is reflected by high Pinus values $(\sim 14 \%)$ at the end of sub-zone X1. Artemisia, a steppe element, reaches $>40 \%$ at the end of the zone.

Zone $Y$ - $350 y r$ BC-AD 550 (Hellenistic-Roman-Byzantine period): Zone $\mathrm{Y}$ is marked by a prominent rise of the Olea curve, which reaches nearly $30 \%$. This reflects extensive olive cultivation in the Judean Hills. Olea was accompanied by other fruit trees such as Juglans and Ceratonia, which make their first appearance in this zone. Vitis and Phoenix were already noted in the previous zone. The marked oscillations of the Olea curve throughout zone Y cannot be explained satisfactorily, but short-term climatic fluctuations cannot be entirely ruled out. The appearance of anthropogenic indicators, such as S. spinosum and Plantago, the curves of which become continuous in the course of this zone, corroborates the anthropogenic interpretation for the rise of olive and the other fruit trees. The radiocarbon date at the top of Zone Y seems to be too old, perhaps caused by redeposition of older carbon.

Zone Z-AD 550-after 1800 (Arab-Modern period): After the olive decline Pinus shows a peak $\sim 15 \%$ in sub-zone $Z 1$ reflecting the onset of forest regeneration. This most probably reflects a decline of anthropogenic pressure on the regional vegetation. Sub-zone $\mathrm{Z} 2$ is 
marked by the highest rise of the evergreen oak pollen curve throughout the entire diagram here reaching nearly $20 \%$. The drop of the oaks in Z3 might be caused by a drier climate at the end of the Little Ice Age or by human disturbances or by a combination of both. The anthropogenic indicators S. spinosum and Plantago reach their highest values.

\subsection{Outcrop ZA2 (Ze'elim)}

The pd of Ze'elim is derived from a $10.75 \mathrm{~m}$ section from an erosion gully in a hyperarid environment where vegetation is almost absent (<100 mm/year, Neumann et al., 2007; Appendix 3). The profile, with lacustrine and fluvial sediments, was used for palaeo-lake reconstructions (Bookman (Ken-Tor) et al., 2004) which were compared to vegetation history (Neumann et al., 2007). The Middle Bronze Age (2000-1550 yr BC) shows high Olea percentages reflecting agriculture when Canaanitic city states were prospering (Neev and Emery, 1995). At the transition to the Late Bronze Age a decrease of oak and olive values and an expansion of Chenopodiaceae might indicate aridity.

Late Bronze Age (1550-1200 yr BC): A pollen sample shows low tree and high herb percentages, e.g. Chenopodiaceae, which might together with the sedimentation of a $110 \mathrm{~cm}$ thick beach ridge point to rather arid conditions.

Iron Age - Persian Period (1200-332 yr BC): Pastoral Judea close to Ze'elim was sparsely settled (Finkelstein, 1995). Peaks of $Q$. calliprinos, Q. boisseri, Pinus and Pistacia are followed by at least two phases with low tree and high chenopod values. The chenopods mainly inhabit the lake shores, which are probably more exposed when the lake level is low as evidenced by several sand layers. At the end of the Iron Age pollen indicators, e.g. Olea (>10\%), show may be slightly moister conditions and a settlement period. Reforestation with slightly higher values of Quercus, Pistacia and Pinus is observed at the transition to the Hellenistic period whereas Chenopodiaceae values are declining.

Hellenistic Period (332-63 yr BC): An increase of cultivated plants shows the growing importance of agriculture. Olea values increase to $\sim 12 \%$, Vitis and the first pollen grains of Juglans are detected. The strong influence of cultivated plants is in agreement with lacustrine sediments, which indicate a rise of the Dead Sea lake level.

Roman Period (63 yr BC-AD 324) and Byzantine Period ( $A D$ 324-638): Juglans, Vitis and Phoenix reach maximal percentages. Olea values increase to $22 \%$. Xanthium, a weed, and Plantago lanceolata, an indicator for grazing and openland (Behre, 1990), signal human disturbances. Around $\sim$ AD 240-430 Olea values dropped to $\sim 2 \%$. Other cultivated plants are missing. Ze'elim is close to ecological border regions (Negev) and might be affected by minor climatic fluctuations. In the Byzantine Period values of cultivated plants, like Olea, rise. Farms and towns prospered in the northern Negev, wheat, olives and grapes were cultivated (Rosen and Finkelstein, 1992; Rubin, 1996). The Dead Sea region was densely settled (Beit-Arieh, 1997). In the 6th century AD Olea decreased.

Early Arab Period (AD 638-1099), Crusaders - Mamelukes (AD 1099-1516): A Pinus peak follows the Olea decrease. The Artemisia curve runs in parallel to Pinus, perhaps pointing to a strong impact of steppe vegetation. A pine decrease is followed by an increase of Q. calliprinos and Sarcopoterium. May be the environment was too dry for a full recovery of the oak forest. $Q$. boisseri remains low.

\subsection{Core DS1 (SE of Ein Gedi)}

Core DS1 was retrieved by M. Stiller in 1979 as a part of joint project of the Department of Geophysics of the Weizman Institute, Israel and the Department of Geophysics of the University of Edinburgh (Stiller et al., 1988). Together with core DS2 the pollen analysis of this core formed part of Baruch's Ph D. dissertation (Baruch, 1993), and is here published in full for the first time (Appendix 4).

Zone X - ca. 1000-350yr BC (Middle to Late Iron Age): Low Q. calliprinos percentages $(<5 \%)$ and relatively high $Q$. boisseri values $(>10 \%)$ characterise this zone. Anthropogenic interpretation is suggested for the generally low arboreal pollen values with the relatively high deciduous oak values pointing to a lower human pressure in the higher forest belt, than in the lower, evergreen-oakdominated lower belt. A comparison between the ratio of both oak types in the samples of zone $\mathrm{X}$ and upper zone $\mathrm{Z}$ clearly shows that in the past deciduous oaks were far more common in the Judean Hills than today. Probably the site was close to stands of deciduous oaks in the northern Judean Hills during the Iron Age. Vitis pollen grains are more prominent in this zone than anywhere else throughout the diagram. This demonstrates that, besides olive, grape culture was also thriving in the area at this period. The local vegetation was dominated by chenopods.

Zone Y - (350 yr BC-550) Hellenistic-Roman-Byzantine period: This zone is marked by the prominent rise of the Olea curve. However, the fact that $Q$. boisseri values remain high indicates that olive cultivation must have been confined mainly to the lower forest zone, which is the natural habitat of the evergreen oak. Olea cannot tolerate temperatures below $-4{ }^{\circ} \mathrm{C}$. Seemingly climate was more favourable for agriculture during the Roman-Byzantine period.

Zone $Z$ - AD 550-after 1800 (Arab-Modern period): The olive decrease is followed by a $Q$. boisseri decline. This sharp decline of the deciduous oaks reflects forest decimation, probably induced by anthropogenic factors, sometime during the concluding centuries of the first millennium AD. The following rise of Pinus reflects a short-termed expansion of this species, made possible by the rather abrupt disappearance of the deciduous oaks and the slow regeneration of evergreen oaks. Horowitz (1992) mentions the oakpine ratio as an indicator for aridity. If this is correct a predominance of pine over oaks might point to aridity. Subsequently the evergreen oaks rise to their highest values throughout the core, which is explained by a possible combination of climatic amelioration and decrease of anthropogenic pressure. The recent decrease of evergreen oaks was caused by human activity. The marked rise of Plantago and Sarcopoterium curves, especially as from sub-zone Z2, points to the basically anthropogenic origin of the phenomena.

\subsection{Core DS7-1SC (NE of Ein Gedi)}

The $3.65 \mathrm{~m}$-long core was recovered at $203 \mathrm{~m}$ water depth in the deep northern basin close to the western border fault of the Dead Sea graben and comprises a sequence of three massive salt layers interrupted by two annually laminated marl units (Appendix 5). AMS ${ }^{14} \mathrm{C}$ dates point to an age of $\sim 749-50 \mathrm{BC}$ at $60 \mathrm{~cm}$ from the base of the section. Post-modern AMS ${ }^{14} \mathrm{C}$ dates were obtained for the top of the profile. The pollen analysis confirms that the white and gray layers were formed during summer (low pollen concentration) whereas dark layers were deposited in autumn, winter and spring (high pollen concentration; Leroy in Heim et al., 1997; S. Leroy, unpublished data). The following descriptions of the pollen zones are given in Heim et al. (1997) and in S. Leroy, unpublished data.

Zones 1, 2: 332-63 yr BC Hellenistic-Roman-Byzantine period: Olea and Vitis values are high. With the exception of the lowermost part of zone 1 , sediments are laminated and point to a humid environment. The lowermost part of zone 1 might belong to the late Iron Age. The halite layer from 3.65 to $3.20 \mathrm{~m}$ depth (with only one pollen spectrum dominated by chenopods) suggests arid conditions. 
Zone 3a: Early Arab Period (638-1099 AD): This zone might have started already in the late Byzantine period. An abandonment of cultivated land is indicated by the drop of the olive values and the absence of Vitis. In contrast steppe vegetation and open dry woodlands become more abundant, e.g. Q. calliprinos, Pistacia and Sarcopoterium, and evidence like the halite layers in zones $3 \mathrm{a}$ and $3 \mathrm{~b}$ show more arid conditions. The decline of cultivated plants is accompanied by a brief bell-shaped curve of Pine (zone 3a) and by forest regeneration during zone $3 \mathrm{~b}$.

Zone 3b: Mamelukes-Ottomans (1099-1918 AD): Q. calliprinos replaces Olea in the Judean Hills. Aridity is shown by a halite unit.

Zones 3c, 3d: WWI-modern period (1918-Post 1983 AD): Poaceae and other indicators of human activities show a clear increase. The decrease of evergreen oaks might be the consequence of wood cutting in WWI. In zone $3 \mathrm{c}$ a laminated sequence shows more humid conditions. In zone $3 \mathrm{~d}$, southern Hemisphere Neophytes illustrate human impact during the last 100 years (Casuarina and Eucalyptus). Salt forms again, as a result of water withdrawal from the Jordan River.

\subsection{Outcrop EFE (Ein Feshkha)}

The palynology, sedimentology and chronology of the erosion gully at the Ein Feshkha oasis, where Tamarix taxa and P. dactylifera are abundant, were described in Neumann et al. (2007) (Appendix 6 ). The $5.85 \mathrm{~m}$-long section is predominantly lacustrine and was compared with and correlated to the section of Ze'elim.

Zone 1, Late Bronze Age (1550-1200 yr BC): A beach ridge at a depth of $5.8 \mathrm{~m}$ indicates aridity. Settlements and cultivated land were abandoned (Finkelstein, 1988). The pd of Ein Feshkha shows low tree pollen values up to a depth of $5.4 \mathrm{~m}$. Olea and oak percentages reach $5 \%$.

Zones 2 - 1st half of zone 4, Iron Age-Persian Period (1200$332 \mathrm{yr} B C$ ): The pd shows an Olea peak at the beginning of the Iron Age, values of Phoenix are high. This might be a signal for agriculture perhaps supported by higher rainfall. High Chenopodiaceae values point to a large influence of desert vegetation. The population during Iron Age I was concentrated north of Jerusalem and in the Jordan valley near Ein Feshkha (Finkelstein, 1995). At a depth of $495 \mathrm{~cm}$, the Chenopodiaceae values increase, and low Olea values perhaps indicate a drop in rainfall. Abandonment of settlements during the 10th century BC or Assyrian destructions during the 8th century BC (Dever, 1995; Náaman, 1992) might be linked to this period of droughts. It cannot be excluded that a peak of Pinus, Quercus and Pistacia might be the consequence of higher precipitation. At the end of the period a settlement phase is visible by an increase of Olea. Oak values decline, probably due to wood cutting.

End of zone 4 to 1 st half of 5, Hellenistic Period (332-63 yr BC): Olea increases, Juglans appears and Chenopodiaceae are decreasing. This might indicate humid conditions, which allow some agriculture. Plantago lanceolata occurs more regularly. Oaks decrease perhaps as a result of deforestation.

2nd half of zone 5-6, Roman-Byzantine Period (63 yr BC-638 yr $A D$ ): Ein Feshkha is close to agricultural centres in the Judean Hills and in oases. Olea reaches $\sim 32 \%$. Pollen grains of Vitis, Phoenix and Juglans are detected regularly. Ceratonia might grow near Ein Feshkha. Plantago indicates grazing. Higher values of Pistacia, Q. calliprinos and Sarcopoterium might point to an expansion of the maquis in the Byzantine period. Values of $Q$. boisseri remain low, apparently indicating that under conditions of strong human disturbances evergreen oaks are more competitive. Vitis, Phoenix and Ceratonia are absent at the end of the Byzantine period, which might point to a degradation of agriculture, although Olea values are still high.
Zones 7, 8, Early Arab Period (AD 638-1099), Crusaders - Mamelukes (AD 1099-1516): At the transition to the Early Arab period Olea declines. Pinus values are rising to $\sim 15 \%$. A 2 nd step in forest regeneration is shown by the increase of $Q$. calliprinos following the decline of pines. The top of the Ein Feshkha profile, dated to AD $1240-1400$, is characterised by higher values of Olea and Vitis. This weakly pronounced settlement phase might be within the Crusader or Mameluke Period when the lake level was higher and rainfall was increasing (Issar and Zohar, 2004).

\section{Reconstruction of the Dead Sea lake level}

The curve of the lake levels reconstructed at the erosion gullies of Ze'elim and Nahal David (Bookman (Ken-Tor) et al., 2004) (Fig. 2) was chosen for a comparison with the pollen records because it covers the same time span represented in the pds. Bookman (KenTor) et al. (2004) have worked in the erosion gully in the Ze'elim wadi from where Neumann et al. (2007) have taken their pollen samples. It allows a direct comparison between the vegetation development and the fluctuations of the Dead Sea lake level. The curve is based on shoreline identification and radiocarbon ages. The lake level oscillations are associated with average annual precipitation in the southern Levant (Enzel et al., 2003). Highstands occurred during the 2nd and 1st century BC and during the 4th century AD. Additional wet periods were recorded in the 11th and 12 th century AD and at the end of the 19th century. We correlate the Ze'elim pd including the lake level reconstruction to the pds at Ein Gedi, Ein Feshkha and Mount Sedom. Alternation between salts and laminated units in DS7-1SC core are also useful lake level indicators.

\section{Vegetation history and past societies}

Palynological investigations of Holocene vegetation history are available from six sites. ${ }^{14} \mathrm{C}$ dates are available for four sites (EFE, ZA2, DS7-1SC, DS2) (Baruch, 1993; Heim et al., 1997; Neumann et al., 2007) (Fig. 2). Cores DS1 and DS3 are not radiometrically dated (Baruch, 1993; Heim et al., 1997; Neumann et al., 2007) (Fig. 2). A comparison between pds starts in the Late Bronze Age (Fig. 2). This must however be taken with caution since radiocarbon dates are often missing or insufficient, resolution is often low and the correlation of the diagrams is predominantly based on pollen. All pds show a remarkably similar succession of pollen zones.

In the Late Bronze Age, represented in the pds of Ein Feshkha and Ze'elim, herb values reach a maximum (Appendices 3 and 6). The values of cultivated plants like Olea and Mediterranean trees (Fig. 2: Q. calliprinos, Pinus) are low. The lake level drops to $-417 \mathrm{~m}$. So lake level reconstruction and pollen data jointly point to relatively arid conditions (Miller Rosen, 2007). The beach ridge, indicator for a low level around 1510-1400 yr BC, and higher Chenopodiaceae values in Ze'elim might be an indicator for aridity in the South of the Dead Sea region. The southern basin of the Dead Sea was dry (Frumkin et al., 1991). Enzel et al. (2003) emphasize that a drop of the lake level below the sill $(-402 \mathrm{~m})$ means that annual rainfall must have been below the modern mean rainfall and prolonged droughts must have prevailed in the Levant. It is possible that the bottom part of the Sedom diagram, showing very low tree and high chenopod values, belongs to the Late Bronze Age (Fig. 2, Appendix 1). The Late Bronze Age is, in agreement with the possibly unfavourable climate, a period of cultural decline in the region when many sites were abandoned and few rural settlements existed in the highlands (Finkelstein, 1988).

The Iron Age is well documented in the six pds, but sharp differentiation with the Hellenistic period and the Late Bronze Age is often not possible. Vegetation in all locations shows similar developments. A slow increase of Olea can be observed until $\sim 10 \%$ 


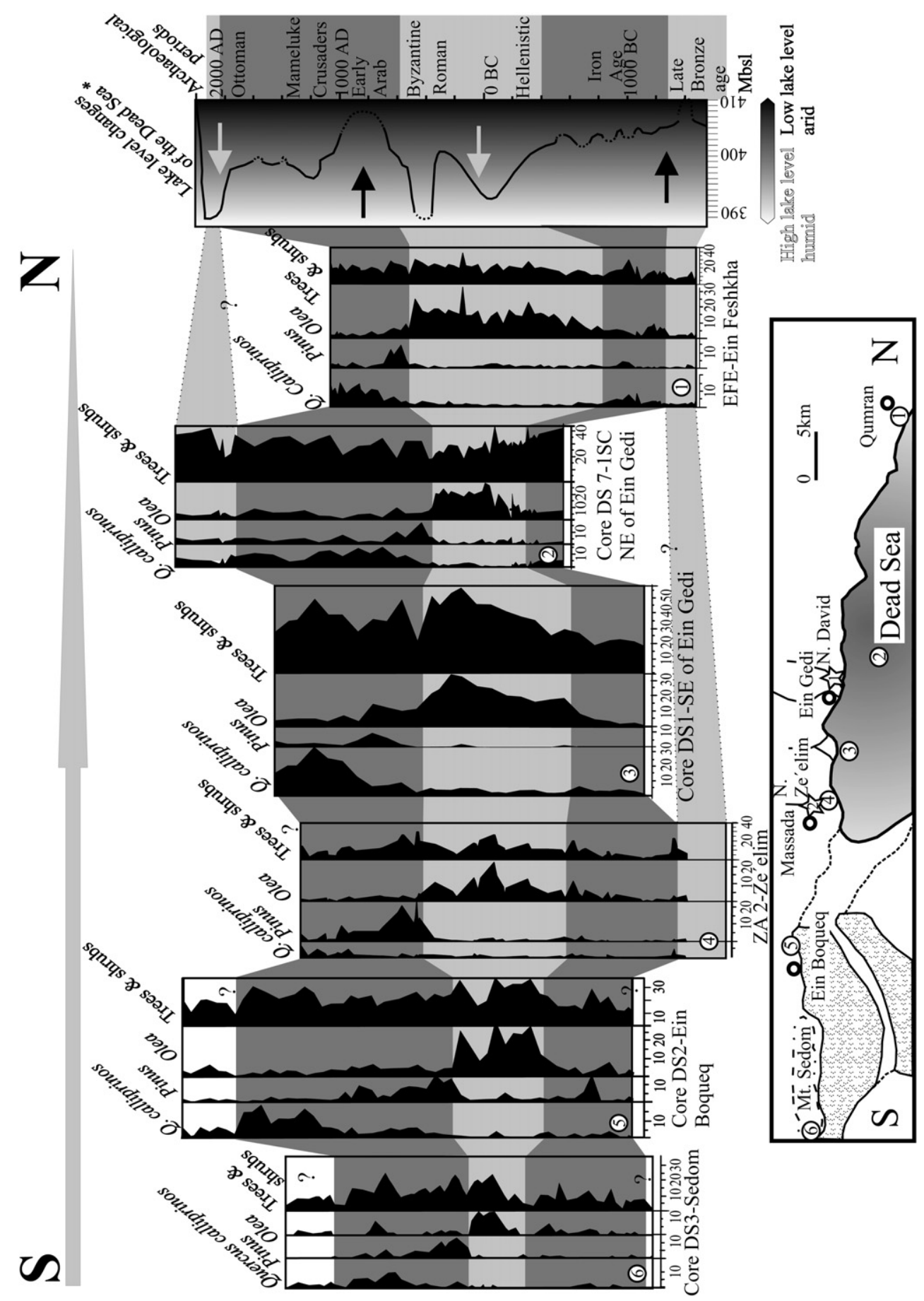

Fig. 2. Comparison of pds from the Dead Sea area (references in Fig. 1) to Dead Sea lake level changes since the Late Bronze Age (after Bookman (Ken-Tor) et al., 2004; Migowski et al., 2006). Four main pollen curves are given ( $Q$ calliprinos, Pinus - members of the Mediterranean forests and maquis, Olea - the most important cultivated plant and the curve of trees \& shrubs). Further pollen information for the sites is available from Appendices 1-6 (electronic version only). The illustration at the bottom shows the location of each of the sites along the western shore of the Dead Sea from S to N (details see Fig. 1). *Bookman (Ken-Tor) et al., 2004. The curve of trees \& shrubs sums all arboreal pollen.

are reached in all pds (Fig. 2). In the same period a decrease of herbs, e.g. Chenopodiaceae, is observed. The olive rise reflects expansion of olive cultivation. Additionally the rise of the lake level from $\sim 405$ to $\sim 401 \mathrm{mbsl}$ points to more humid conditions at the end of the Iron Age, although several sand layers in the pd of Ze'elim indicate aridity during certain periods of the Iron Age. The pd of DS7-1SC might start in the late Iron Age although an allocation to this period is uncertain. Low tree values at the beginning of the diagram and the deposition of a salt layer might signal a lake level drop during the end of the Iron Age. An Olea peak followed by forest regeneration is observed in the pds of DS2, ZA2 and EFE. Pinus is increasing in DS2 whereas the rise of the pine curve is accompanied by $Q$. calliprinos and $Q$. boisseri increases in ZA2 and EFE. Apparently a short-term settlement period is a common signal throughout the region. It is uncertain if the expansion of cultivation is triggered by a more favourable climate. The steady rise of the lake level towards the end of this period, points to climatic amelioration at the end of the Iron Age and the onset of the Hellenistic Period. 
The diagram of Ze'elim (ZA2) shows increasing values of Olea at the end of the Iron Age but also a short-term drop of tree pollen which might be correlated to a lake level decrease $\sim 500 \mathrm{yr}$ BC.

During the Hellenistic, Roman and Byzantine period, Quercus and Pinus values show a decrease due to forest clearings (more pronounced in Ein Feshkha and Ein Gedi) and olive values strongly rise. This is in good agreement with evidence showing an increase of settlements and agriculture along with a climatic amelioration (Issar and Zohar, 2004). Q. boisseri values in the pds of EFE and, more pronounced, DS1 remain relatively high. This indicates that the lower forest belt was more disturbed than the higher regions. The Roman and Byzantine periods were relatively humid as reflected by higher lake levels (Fig. 2). Roman-Byzantine olive cultivation is mostly distinguished in the pds near Ein Gedi (>30\%), whereas Olea values in Sedom and Ze'elim are $\sim 15 \%$. Minor fluctuations of the Dead Sea level, e.g. the drop during the 3rd-5th century AD, where aridity is reported by archaeological investigations (Bruins, 1994), might be correlated with decreases in the Olea values that can be observed in the pds of ZA2, DS2 and DS1 at the end of this period. Olea values are higher in the pds of DS1 (maximally 35\%), DS7-1SC and Ein Feshkha (maximally $32 \%)$, a consequence of intensified agriculture in the Judean Hills (Neumann et al., 2007). Probably the wind regime at the NW corner of the lake, where EFE is located, is more dominated by winds coming from N and NW (Bitan, 1974). The influence of the desert vegetation in the Jordan valley might be stronger in Ein Feshkha than in Ein Gedi. The pd of core DS2 near Ein Boqueq shows similar Olea values to that of Ein Feshkha (maximally 32\%). Olives were probably cultivated to the West of the site in the Negev, where settlements and farms prospered (Rubin, 1996). It is possible, although unlikely, that olive trees were cultivated near Ein Boqueq for the local perfume production - olive oil was the base of the perfume - as was the case in the arid Arava site of Moyat 'Avad during the late 2nd and early 3rd century AD. However, archaeological or historical evidence is missing (Brun, 2000; personal communication F. Erickson-Gini). Olea values in the south are, with the exception of DS2, lower than in the north, pointing to more arid environments and a longer distance between regions where olives are growing in the Mediterranean Judean Hills and the southern sites. At the end of the Byzantine period Olea values abruptly decrease at all sites. This might be the result of the Arab occupation of Palestine in AD 638 (Baruch, 1986, 1990; Baruch and Bottema, 1999), or an arid climate resulting in the drop of the Dead Sea lake level starting in the late 5th century AD (S. Leroy, unpublished data) (Fig. 2).

The Early Arab until Ottoman period is characterized by low 0 . europea values. The period is characterised by a decrease of agriculture and population and possibly drier climate if compared to the Byzantine period (Issar and Zohar, 2004). Pinus shows a strong peak in the pds of the Dead Sea region. This signal is characteristic for pollen records in the Dead Sea region and reflects a regional effect. $P$. halepensis, fast growing, specialized to unfavourable soils and a common pioneer, might have invaded abandoned orchards (Néeman et al., 2004). Arid periods might cause prevalence of Pinus over Quercus, because pines are adapted to droughts. The Pinus abundance can be seen as a sign for aridity also shown by the decrease of the Dead Sea level (Bookman (KenTor) et al., 2004). The seedlings are sensitive to overshadowing and are suppressed by deciduous trees (Rabinowitch-Vin, 1982). The forest regeneration, led by pines and followed by evergreen oaks, might be the consequence of the abandonment of cultivated fields and settlements and the decrease of wood cutting at the transition from the Byzantine to the Early Arab period. According to Horowitz (1992), arid periods cause a high pine/oak ratio which is observed in all six pds in the Dead Sea region following the collapse of the Olea values. A pronounced peak of $Q$. calliprinos can be observed in the pds DS1, DS2, DS3, EFE and DS7-1SC. There is a possibility that those peaks might be a result of a wetter climate in the medieval period. The most recent decline of $Q$. calliprinos might be explained by human impact or by an arid period at the end of the Little Ice Age (Baruch, 1990). Between AD 1400 and 1600 the lake level of the Dead Sea drops (Fig. 2). In the profile of Ze'elim a sand layer was formed AD 1210-1420. The values for the Mediterranean $Q$. calliprinos are much higher in the northern pds, which might be a result of the shorter distance to the mostly Mediterranean Judean Hills. The values of $Q$. calliprinos are less pronounced in the pds of Ze'elim and Ein Feshkha, but are highest at the top of the profiles. This might be a consequence of erosion, which led to the destruction of the uppermost sequences at both sites. Pollen data from the Modern period showing Neophyte pollen (Casuarina, Carya, Eucalyptus) are available from core DS7-1SC. The retreat of the evergreen oaks is may be a consequence of wood cutting in WW I. Slightly higher values of oaks and olives might be a consequence of climate amelioration and plantation during the first half of the 20th century (high lake level of the Dead Sea; Fig. 2).

\section{Conclusion}

1. The study of surface samples clearly demonstrates that the origin of pollen influx into the Dead Sea is primarily in the region west of the lake, i.e. the Judean Hills. This is extrapolated to the interpretation of six sedimentary sequences at the west shores of the Dead Sea along a $75 \mathrm{~km}$ long transect. The changes in the Mediterranean vegetation, broadly similar and synchronous in all pds, are interpreted as changes mostly in the vegetation of the Judean Hills.

2. There is a broad synchronism between the fluctuations of cultivation, vegetation, lithology and climate change in the Dead Sea region during the last $\sim 3500$ years as derived from pollen data, sediments and lake level reconstructions along the western shore of the Dead Sea. In the Iron Age and Hellenistic to Byzantine Period the lake level reconstruction of the Dead Sea, as well as laminated sediments in the profiles of ZA2, EFE and DS7-1SC, point to a more humid climate. In the same periods values of cultivated plants are high in the pds and indicate an increase of agriculture. These were periods of more intensive agriculture activity due to socio-economic activity in the area west of the Dead Sea. The possible contribution of favourable climatic conditions to the expansion of agriculture and horticulture in these times cannot be ruled out. Low lake levels during the Late Bronze Age, the Iron Age and at the end of the Byzantine period point to climatic deterioration, which may contribute to the decrease of cultivated plants. This suggestion is strengthened by the deposition of sand layers in ZA2 and EFE and halite layers in DS7-1SC during those arid periods. In general cultural factors should be considered to be of least equal, if not higher, importance in affecting the intensity and extent of agriculture.

3. It is clear from all pds that Mediterranean trees, e.g. Q. calliprinos, $Q$. boisseri, Pistacia and Pinus, are largely replaced by cultivated plants during settlement periods. Cultivation developed mainly in the Mediterranean territory which was more favourable for settlers. Judging from relatively high Q. boisseri values in comparison to low $Q$. calliprinos values during the Roman-Byzantine period in the pds of EFE and DS1 settlements were concentrated, at least in the vicinity of those sites, in the lower $Q$. calliprinos forest belt whereas the higher regions were less affected. 
4. Forest regeneration is clearly pronounced in all pds after the agricultural decline at the end of the Byzantine period. Drought-resistant and fast-growing pines are soon overshadowed by oaks especially evergreen oak and its regular companions Pistacia and Sarcopoterium. We conclude that the collapse of the settlement system near the transition to the Early Arab period affected the whole study area. Forest regeneration can be detected during the end of the Iron Age in the pds of Ein Boqueq, Ze'elim and Ein Feshkha after a short-lived and limited period of olive cultivation. The forest regeneration is soon interrupted at the transition to the Hellenistic period, probably by wood cutting at the beginning of a new settlement period.

5. The relatively higher frequencies of anthropogenic indicators, e.g. Sarcopoterium, in the pollen record from the Hellenistic period on, seem to indicate that from now on the Mediterranean vegetation was never free of anthropogenic pressure. This may imply that the Mediterranean maquis, as we know it today in the Judean Mountains, started to take shape some 13001400 years ago.

6. Although similarities of pollen fluctuations dominate in all pds, regional variations in pollen distribution are observed along the transect. Mediterranean vegetation elements and cultivated plants are less pronounced in the pds to the South (Ze'elim, Sedom) and stronger in the diagrams in the north (Ein Gedi, Ein Feshkha). This can be explained by a shorter distance from the sites near Ein Feshkha and Ein Gedi to settlement centres and to the Mediterranean plant geographical territory in the Judean Hills. Oases, centres of agriculture, exist near Ein Feshkha and at Ein Gedi and might be a source for some pollen of locally cultivated plants (Phoenix).

7. The pollen results might point to regions to the west of the sites where agriculture and settlement activities are concentrated. The pds of DS1 and DS7-1SC, showing the highest Olea values of all pds, reflect Roman-Byzantine centres of agriculture in the Judean Hills. The high Olea, Vitis, Phoenix and Juglans percentages in the pd of DS2 near Ein Boqueq during the Roman-Byzantine period might be a consequence of enhanced agriculture in the Negev.

8. Some Mediterranean elements and crops, e.g. Q. boisseri, Pistacia, and Olea, in EFE show lower values than in the pd of DS71SC near Ein Gedi to the South. This might be connected to a predominance of winds from the $\mathrm{N}$ and $\mathrm{NW}$ leading to a higher influence of the desert and oasis vegetation (e.g. Chenopodiaceae, Phoenix) because the lower Jordan valley and the region around Jericho are dominated by Saharo-Arabian and, to a lesser degree, Sudano-Deccanian vegetation

\section{Acknowledgements}

We thank Mordechai Stein, Jodi Magness, Tali Erickson-Gini, Rehav Rubin and Wolfgang Zwickel for helpful discussions and literature and the editors of this volume for the invitation to publish in Journal of Arid Environments.

Michael Turner has kindly revised the English of the manuscript.

\section{Appendix. Supplementary data}

Supplementary data associated with this article can be found in the online version, at doi:10.1016/j.jaridenv.2009.04.015

\section{References}

Al-Eisawi, D., 1996. Vegetation of Jordan. UNESCO, Regional Office for Science and Technology for the Arab States, Cairo, Egypt.
Baruch, U., 1986. The Late Holocene vegetational History of lake Kinneret (Sea of Galilee), Israel. Paleorient 12/2, 37-48.

Baruch, U., 1990. Palynological evidence of human impact on the vegetation as recorded in late Holocene lake sediments in Israel. In: Bottema, S., EntjesNieborg, G., Van Zeist, W. (Eds.), Man's Role in the Shaping of the Eastern Mediterranean Landscape. Balkema, Rotterdam, pp. 283-293.

Baruch, U., 1993. The Palynology of Late Quaternary Sediments of the Dead Sea. Unpubl. Ph.D. thesis, Hebrew University of Jerusalem, Jerusalem (Hebrew with English summary).

Baruch, U., Bottema, S., 1999. A new Pd from lake Hula - vegetational, climatic and anthropogenic implications. In: Kawanabe, H., Coulter, G.W., Roosevelt, A.C. (Eds.), Ancient Lakes: Their Cultural and Biological Diversity. Kenobi Productions, Belgium, pp. 75-86.

Behre, K.-E., 1990. Some reflections on anthropogenic indicators and the record of prehistoric occupation phases in pollen diagrams from the near east. In: Bottema, S., Entjes-Nieborg, G., van Zeist, W. (Eds.), Man`s Role in the Shaping of the Eastern Mediterranean Landscape. Balkema, Rotterdam.

Beit-Arieh, I., 1997. The Dead Sea region: an archaeological perspective. In: Niemi, T.M., Ben Avraham, Z., Gat, J.R. (Eds.), The Dead Sea - the Lake and Its Settings. Oxford University Press, New York-Oxford, pp. 249-251.

Ben-Itzhak, L.L., Gvirtzman, H., 2005. Groundwater flow along and across structural folding: an example from the Judean Desert. Journal of Hydrology 312, 51-69.

Ben Moshe, L., Haviv, I., Enzel, Y., Zilberman, E., Matmon, A., 2008. Incision of alluvial channels in response to a continuous base level fall: field characterisation, modeling, and validation along the Dead Sea. Geomorphology 93, 524-536.

Bitan, A., 1974. The wind regime in the north-west section of the Dead-Sea. Archives for Meteorology Geophysics and Bioclimatology Series B 22, 313-335.

Bookman, R., Bartov, Y., Enzel, Y., Stein, M., 2006. Quaternary lake levels in the Dead Sea basin: two centuries of research. In: Enzel, Y., Agnon, A., Stein, M. (Eds.), New Frontiers in Dead Sea Palaeoenvironmental Research. Geological Society of America. doi:10.1130/2006.2410(10) Special Publication 401.

Bookman (Ken-Tor), R., Enzel, Y., Agnon, A., Stein, M., May/June 2004. Late Holocene lake levels of the Dead Sea. Geological Society of America Bulletin 116 (5/6), 555-571.

Bruins, H.J., 1994. Comparative chronology of climate and human history in the southern Levant from the late chalcolithic to the early Arab Period. In: Late Quaternary Chronology and Palaeoclimates of the Eastern Mediterranean. Radiocarbon, Tucson, pp. 301-315

Brun, J.-P., 2000. The production of perfumes in antiquity: the cases of Delos and Paestum. American Journal of Archaeology 104 (2), 277-308.

Danin, A., 1988. Flora and vegetation of Israel and adjacent areas. In: Yom Tov, Y, Tchernov, E. (Eds.), The Zoogeography of Israel: 129-159. Dr. W. Junk Publishers, Dordrecht-Boston-Lancaster, pp. 129-159.

Danin, A., 1995. Man and the natural environment. In: Levy, T.E. (Ed.), The Archaeology of Society in the Holy Land: 24-39. Leicester University Press, London, pp. 24-39.

Danin, A., Plittmann, U., 1987. Revision of the plantgeographical territories of Israel and Sinai. Plant Systematics and Evolution 156, S.43-S.53.

Danin, A., Orshan, G. (Eds.), 1999. Vegetation of Israel-I. Desert and Coastal Vegetation. Backhuys Publishers, Leiden, The Netherlands.

Dayan, U., Morin, E., 2006. Flash flood-producing rainstorms over the Dead Sea: a review. Geological Society of America Special Paper 401, 53-62.

Dever, W.G., 1995. Social structure in Palestine in the Iron II Period on the eve of destruction. In: Levy, T.E. (Ed.), The Archaeology of Society in the Holy Land. Leicester University Press, London, pp. 416-431.

El-Naqa, A., 1993. Hydrological and hydrogeological characteristics of Wadi el Mujib catchment area, Jordan. Environmental Geology 22 (3), 257-271.

Enzel, Y., Bookman, R., Sharon, D., Gvirtzman, H., Dayan, U., Ziv, B., Stein, M., 2003. Late Holocene climates of the near east deduced from Dead Sea level variations and modern regional winter rainfall. Ouaternary Research 60, 263-273.

Feinbrun-Dothan, N., Danin, A., 1991. Analytical Flora of Eretz Israel. CANA, Publishing Houses Ltd., Jerusalem.

Finkelstein, I., 1988. The Archaeology of the Israelite Settlements. Israel Exploration Society, Israel.

Finkelstein, I., 1995. The great transformation: the conquest of the highland frontiers and the rise of the territorial states. In: Levy, T.E. (Ed.), The Archaeology of Society in the Holy Land. Leicester University Press, London, pp. 349-367.

Freund, R., Garfunkel, Z., Zak, I., Goldberg, M., Weissbrod, T., Derin, B., 1970. The shear along the Dead Sea rift. Philosophical Transactions of the Royal Society of London A. 267, 107-130.

Frumkin, A., 1997. The Holocene history of Dead Sea levels. In: Niemi, T. (Ed.), The Dead Sea - the Lake and Its Settings. Oxford University Press, New York-Oxford, pp. 237-249.

Frumkin, A., Elitzur, Y, 2002. Historic Dead Sea level fluctuations calibrated with geological and archaeological evidence. Quaternary Research 57, 334-342.

Frumkin, A., Margaritz, M., Carmi, I., Zak, I., 1991. The Holocene climatic record of the salt caves of Mount Sedom. The Holocene 1, 191-200.

Garfunkel, Z., Ben-Avraham, Z., 1996. The structure of the Dead Sea basin. Tectonophysics $266,155-176$

Gavrieli, I., Lensky, N.G., Dvorkin, Y., Gertman, I., Lyakhovsky, V., 2006. The Dead Sea: a highly disturbed water balance, outcomes and possible solutions. Geophysical Research Abstracts 8, EGU 2006.

Hecht, A., Ezer, T., Huss, A., Shapira, A., 1997. Wind waves on the Dead Sea. In: Niemi, T.M., Ben Avraham, Z., Gat, J.R. (Eds.), The Dead Sea - the Lake and Its Settings. Oxford University Press, New York-Oxford, pp. 114-121. 
Heim, C., Nowaczyk, N.R., Negendank, J.F.W., Leroy, S.A.G., Ben-Avraham, Z., 1997. Near east desertification: evidence from the Dead Sea. Naturwissenschaften 1984, 398-401.

Horowitz, A., 1992. Palynology of Arid Lands. Elsevier Science, Amsterdam-LondonNew York-Tokyo.

Issar, A.S., Zohar, M., 2004. Climate Change - Environment and Civilization in the Middle East. Springer, Berlin-Heidelberg

Jaffe, S., 1988. Climate of Israel. In: Yom Tov, Y., Tchernov, E. (Eds.), The Zoogeography of Israel: 79-95. Dr. W. Junk Publishers, Dordrecht-Boston-Lancaster.

Klein, C., Flohn, H., 1987. Contributions to the knowledge of the fluctuations of the Dead Sea level. Theoretical and Applied Climatology 38, 151-156.

Klinger, Y., Avouac, J.P., Bourles, D., Tisnerat, N., 2003. Alluvial deposition and lakelevel fluctuations forced by late Quaternary climate change: the Dead Sea case example. Sedimentary Geology 162, 119-139.

Lamb, H.F., 1982. Climate History and the Modern World. Methuen, London.

Migowski, C., Stein, M., Prasad, S., Negendank, J.F.W., Agnon, A., 2006. Holocene climate variability and cultural evolution in the near east from the Dead Sea sedimentary record. Quaternary Research 66/3, 421-431.

Miller Rosen, A., 2007. Civilizing Climate - Social Responses to Climate Change in the Ancient Near East. Altamira Press, Lanham-New York-Toronto-Plymouth, UK.

Náaman, N., 1992. Israel, Edom and Egypt in the 10th Century B.C.E. Tel Aviv 19, 71-93.

Néeman, G., Goubitz, S., Nathan, R., 2004. Reproductive traits of Pinus halepensis in the light of fire - a critical review. Plant Ecology 171, 69-79.

Neev, D., Emery, K.O., 1967. The Dead Sea: depositional processes and environments of evaporites. Geological Survey of Israel Bulletin 41 Jerusalem.

Neev, D., Emery, K.O., 1995. The Destruction of Sodom, Gomorrah and Jericho Geological, Climatological and Archaeological Background. Oxford University Press, New York-Oxford.

Neumann, F.H., Kagan, E.J., Schwab, M., Stein, M., 2007. Palynology, sedimentology and palaeoecology of the late Holocene Dead Sea. Quaternary Science Review $26,1476-1498$.
Nissenbaum, A., 1993. The Dead Sea - an economic resource for 10000 years. Hydrobiologia 267, 127-141.

Rabinowitch-Vin, A., 1982. Pinus halepensis. In: Alon, A. (Ed.), Plants and Animals of the Land of Israel. Flowering Plants A, vol. 10, pp. 17-18 (in Hebrew).

Rosen, B., Finkelstein, I., 1992. Subsistence patterns, carrying capacity and settlement oscillations in the Negev highlands. Palestine Exploration Quarterly, 42-58.

Rubin, R., 1996. Urbanization and settlement in the Negev Desert in the Byzantine period. In: Gradus, Y., Lipshitz, G. (Eds.), The Mosaic of Israeli Geography. Ben Gurion Press, Beersheva, pp. 373-401.

Singer, A., Ganor, E., Dultz, S., Fischer, W., 2003. Dust deposition over the Dead Sea. Journal of Arid Environments 53, 41-59.

Stein, M., 2001. The sedimentary and geochemical record of Neogene - Quaternary water bodies in the Dead Sea basin - inferences for the regional paleoclimatic history. Journal of Paleolimnology 21, 271-282.

Stiller, M., Carmi, I., Kaufman, A., 1988. Organic and inorganic ${ }^{14} \mathrm{C}$ concentrations in the sediments of lake Kinneret and the Dead Sea (Israel) and the factors controlling them. Chemical Geology 73, 1-16.

Stuiver, N., Reimer, P.J., 1993. Extended revised CALIB $3.0{ }^{14} \mathrm{C}$ age calibration program. Radiocarbon 35 (19), 215-230.

Walter, H., Breckle, S.-W., 1999. Vegetation und Klimazonen. 7. Auflage. Verlag Eugen Ulmer, Stuttgart.

Weiss, H., Bradley, 2001. What drives societal collapse? Science 291, 609-610.

Yakir, D., Issar, A., Gat, J., Adar, E., Trimborn, P., Lipp, J., $1994 .{ }^{13} \mathrm{C}$ and ${ }^{18} \mathrm{O}$ of wood from the Roman siege rampart in Masada, Israel (AD 70-73): evidence for a less arid climate of the region. Geochimica et Cosmochimica Acta 58 (16), 3535-3539.

Yechieli, Y., Magaritz, M., Levy, Y., Weber, U., Kafri, U., Wölfli, W., Bonani, G., 1993. Late Quaternary geological history of the Dead Sea area. Israel Quaternary Research 39, 59-67.

Zohary, M., 1983. Man and vegetation in the middle east. In: Holzner, W., Werger M.J.A., Ikusima, I. (Eds.), Man's Impact on Vegetation. The Hague-BostonLondon, pp. 287-295.

Zohary, M., 1995. Pflanzen der Bibel, third ed. Calwer Verlag, Stuttgart. 